\title{
HABITAT DIFFERENTIATION \\ OF THE MYRIOPHYLLUM ALTERNIFLORUM AND LITTORELLA UNIFLORA PHYTOCOENOSES IN POLAND
}

\author{
STANISŁAW KŁOSOWSKI, MARCIN SZAŃKOWSKI \\ Department of Environmental Botany, Institute of Botany \\ University of Warsaw \\ Al. Ujazdowskie 4, 00-478 Warszawa, Poland \\ e-mail: s.klosowski@uw.edu.pl \\ (Received: April 18, 2003. Accepted: February 5, 2004)
}

\begin{abstract}
The present study showed the ecological differentiation of phytocoenoses dominated either by Myriophyllum alterniflorum or by Littorella uniflora, which in Poland are classified within the Myriophylletum alterniflori or Myriophyllo-Littorelletum association. The properties which best differentiated the waters of the above types of phytocoenoses were calcium and factors associated with the carbonate complex ( $\mathrm{pH}$, electrolytic conductivity, total and carbonate hardness), and $\mathrm{pH}$ in the case of substrates. The most distinct differences in the habitats were found between the phytocoenoses dominated by L. uniflora from the Pomeranian Lobelia lakes and those dominated by M. alterniflorum from the Łęczna-Włodawa Lake District, in which other species from the Littorelletea uniflorae class were absent. The $L$. uniflora phytocoenoses are associated with soft waters poor in $\mathrm{Ca}^{2+}$ and with the lowest values of $\mathrm{pH}$, electrolytic conductivity, dissolved organic matter $\left(\mathrm{COD}-\mathrm{KMnO}_{4}\right)$ and dissolved $\mathrm{SiO}_{2}$. The substrates they inhabit are mineral and more acidic. By contrast, the values of the above-mentioned properties are considerably higher in the case of the phytocoenoses from the Łęczna-Włodawa Lake District. The habitats of the $M$. alterniflorum phytocoenoses from the Pomeranian Lobelia lakes occupy an intermediate position and are more similar to those of $M$. alterniflorum from the Łęczna-Włodawa Lake District. The results obtained in this study suggest that the phytocoenoses of L. uniflora and $M$. alterniflorum should not be included in the same association. Further studies are, therefore, necessary to resolve this problem. The comparative analysis of the present ecological findings and data obtained from other regions of Europe show that in Poland the phytocoenoses dominated either by L. uniflora or by M. alterniflorum, in which the contribution of Littorelletea uniflorae species is appreciable, are clearly associated with soft waters and their habitats are representative of the Littorelletea uniflorae class. The massive development of the phytocoenoses with both L. uniflora and M. alterniflorum in the Lobelia lakes is not always indicative of the increase in water hardness and euthrophication of waters typical of the communities of the Littorelletea uniflorae class. The M. alterniflorum dominated phytocoenoses without other Littorelletea species could be good indicators of the above processes taking place in such water ecosystems.
\end{abstract}

KEY WORDS: Myriophyllum alterniflorum and Littorella uniflora phytocoenoses, Littorelletea uniflorae, habitat differentiation, properties of water and substrate, Myriophylletum alterniflori and Myriophyllo-Littorelletum.

\section{INTRODUCTION}

In Poland most of the plant communities of the Littorelletea uniflorae Br.-B1. et R.Tx. 1943 class are known to occur in the western part of the country (Matuszkiewicz 2001). They are confined mainly to soft waters of Lobelia lakes in the Pomeranian Lake District (Dąmbska 1965; Rejewski 1981; Boiński and Boińska 1988; Szmeja and Clément 1990; Kłosowski 1994; Szańkowski and Kłosowski 1996, 2001, 2002; Matuszkiewicz 2001). Among the communities of Littorelletea uniflorae, the phytocoenoses dominated either by Myriophyllum alterniflorum or by Littorella uniflora are highly interesting since:
- the two types of phytocoenoses show a considerable tolerance of the increase in the fertility of soft oligotrophic waters; the spread of M. alterniflorum in Lobelia lakes could be indicative of the progressive eutrophication of the waters (Matuszkiewicz 2001),

- M. alterniflorum phytocoenoses have been found in other types of waters as well (their localities have also been reported from the Łęczna-Włodawa Lake District); their ecological amplitude should, therefore, be well-defined,

- in Poland the phytocoenoses of M. alterniflorum have been identified with various associations, e.g. Myriophylletum alterniflori Westhoff mscr. 1944 (Dąmbska 1965; Kreńska 1971; Michna 1976; Podbielkowski and Tomasze- 
wicz 1979), Myriophylletum alterniflori Lemèe 1937 em. Siss. 1943 (Rejewski 1981; Kłosowski and Tomaszewicz 1989; Kłosowski 1994) or Myriophyllo-Littorelletum Jeschke 1959 (Szmeja 1994; Szańkowski 1998 mscr; Matuszkiewicz 2001), and only either M. alterniflorum (Fijałkowski 1959; Rejewski 1981) or L. uniflora (Dąmbska 1965; Kreńska 1971; Michna 1976; Podbielkowski and Tomaszewicz 1979; Kłosowski 1994; Matuszkiewicz 2001) are recognized as the character species of the above syntaxa.

The above findings show that knowledge on the phytosociology and ecology of the M. alterniflorum and L. uniflora phytocoenoses is insufficient and should, therefore, be supplemented by more data. It is also necessary to evaluate whether these phytocoenoses should be classified as belonging to one association. With regard to all this, detailed phytosociological and habitat studies of the communities of $M$. alterniflorum and L. uniflora were performed within wider research on the ecology of plant communities of the class Littorelletea uniflorae in Poland.

Therefore, the main objectives of this study were:

- to compare the phytocoenoses of M. alterniflorum and L. uniflora from the Pomeranian Lobelia lakes and those of M. alterniflorum from the Łęczna-Włodawa Lake District with respect to phytosociology and habitat conditions,

- to evaluate whether it is justifiable to include the phytocoenoses of M. alterniflorum and L. uniflora in one association,

- to compare the habitats of the above phytocoenoses from Poland with those reported from other regions of Europe.

\section{MATERIAL AND METHODS}

The survey was carried out in the years 1986-1997 within the Pomeranian and Łęczna-Włodawa Lake Districts. All sites were sampled during the height of the growing season (July-August). Altogether the habitats of 46 phytocoenoses (13 with $M$. alterniflorum in 8 Lobelia lakes and 16 with L. uniflora in 12 Lobelia lakes from the Pomeranian Lake District, and 17 dominated by $M$. alterniflorum in 7 lakes from the Łęczna-Włodawa Lake District) were investigated. In each phytocoenosis one phytosociological relevé was recorded by Braun-Blanquet's method. In addition one water and one substrate sample were taken for physical and chemical analyses. Water samples were taken from an intermediate depth at which a given phytocoenosis occurred and transferred to two $1000 \mathrm{ml}$ plastic containers. Half of the water samples were preserved by the addition of $1 \mathrm{ml}$ of $\mathrm{H}_{2} \mathrm{SO}_{4}$ for $\mathrm{NO}_{3}{ }^{-}, \mathrm{PO}_{4}{ }^{3-}$, total $\mathrm{Fe}$ and $\mathrm{COD}-\mathrm{KMnO}_{4}$ analyses. Substrate samples were taken from the rhizomeroot layer with a tubular bottom sampler and transferred to plastic bags. Each sample was a mixture of a few random subsamples taken within a phytocoenosis.

The following determinations were carried out in water samples: $\mathrm{pH}$ (using $\mathrm{pH}$-meter), electrolytic conductivity (EC) by means of a conductivity meter, total and carbonate hardness using Warthy-Pfeifer sodium mixture and by titration with EDTA reagent and ManVer 2 as an indicator, chemical oxygen demand (COD) as consumption of $\mathrm{KMnO}_{4}$ in acid medium, $\mathrm{PO}_{4}{ }^{3-}$ spectrophotometrically by molybdate method, $\mathrm{NO}_{3}{ }^{-}$spectrophotometrically with phenoldisulphonic acid and by the cadmium reduction method, total $\mathrm{Fe}$ spectrophotometrically by the rhodanate method, dissolved $\mathrm{SiO}_{2}$ spectrophotometrically by the molybdate method, $\mathrm{Ca}^{2+}, \mathrm{Na}^{+}$and $\mathrm{K}^{+}$with a flame spectrophotometer.

In the substrate samples, the following properties were assessed directly; $\mathrm{pH}$, hydration and organic matter content. Concentrations of dissolved $\mathrm{SiO}_{2}$ were determined in solutions extracted by addition of $100 \mathrm{ml}$ of demineralized water to a substrate sample containing $1 \mathrm{~g}$ of dry matter (water extracts). In the case of solutions used for determi-

TABLE 1. Synoptic phytosociological data of the phytocoenoses studied. L - phytocoenoses dominated by L. uniflora (Pomeranian Lobelia lakes); M1 - phytocoenoses dominated by M. alterniflorum (Pomeranian Lobelia lakes); M2 - phytocoenoses dominated by $M$. alterniflorum (Łęczna-Włodawa Lake District).

Constancy: I, II...V; Abundance: $+, 1,2 \ldots 5$.

\begin{tabular}{|c|c|c|c|}
\hline Types of phytocoenoses & $\mathrm{L}$ & M1 & M2 \\
\hline Number of relevés & 16 & 13 & 17 \\
\hline Littorella uniflora & $\mathrm{V}^{4-5}$ & $\mathrm{II}^{+-3}$ & \\
\hline Myriophyllum alterniflorum & $\mathrm{III}^{+-3}$ & $\mathrm{~V}^{4-5}$ & $\mathrm{~V}^{4-5}$ \\
\hline \multicolumn{4}{|l|}{ Ch. Littorelletea uniflorae } \\
\hline Lobelia dortmanna & $\mathrm{IV}^{+-2}$ & $\mathrm{II}^{+-1}$ & \\
\hline Isoëtes lacustris & $\mathrm{IV}^{+-1}$ & $\mathrm{I}^{+}$ & \\
\hline Eleocharis acicularis & $\mathrm{I}^{+-1}$ & $\mathrm{I}^{+}$ & \\
\hline Luronium natans & $\mathrm{I}^{+}$ & $\mathrm{II}^{+}$ & \\
\hline Nitella flexilis & $\mathrm{I}^{+}$ & & \\
\hline Elatine hydropiper & $\mathrm{I}^{+}$ & & \\
\hline Juncus bulbosus & & $\mathrm{I}^{1}$ & \\
\hline Ranunculus reptans & & $\mathrm{I}^{+}$ & \\
\hline Chara delicatula & & $\mathrm{I}^{+}$ & \\
\hline
\end{tabular}

Ch. Potametea

Polygonum amphibium

Elodea canadensis

Nuphar lutea

Potamogeton obtusifolius

Myriophyllum spicatum

Potamogeton natans

Ceratophyllum demersum

Nuphar pumila

Myriophyllum verticillatum

Potamogeton sp.

Stratiotes aloides

Nymphaea alba

Potamogeton lucens

Potamogeton perfoliatus

Potamogeton friesii

Nymphaea candida

$\mathrm{II}^{+}$

$\mathrm{I}^{+-2} \quad \mathrm{III}^{+-2} \quad \mathrm{II}^{+}$

Ch. Phragmitetea

Eleocharis palustris

Equisetum fluviatile

Carex rostrata

Phragmites australis

Schoenoplectus lacustris

Acorus calamus

Accompanying species

Fontinalis antipyretica

Drepanocladus tenuinervis

Lemna trisulca

Chara fragilis

Callitriche hamulata

Chara sp.

Nitellopsis obtusa
$\mathrm{I}^{+} \mathrm{I}^{+}$

$\mathrm{I}^{+}$

$\begin{array}{ll}\mathrm{II}^{+} & \mathrm{V}^{+-1} \\ \mathrm{I}^{+} & \mathrm{II}^{+-2} \\ \mathrm{I}^{+} & \mathrm{I}^{+} \\ \mathrm{I}^{+} & \\ \mathrm{I}^{+} & \\ \mathrm{I}^{+} & \\ & \mathrm{II}^{+} \\ & \mathrm{I}^{+} \\ & \mathrm{I}^{+} \\ & \mathrm{I}^{+} \\ & \mathrm{I}^{+} \\ & \mathrm{I}^{+}\end{array}$

$\mathrm{II}^{+}$
$\mathrm{I}^{+}$
$\mathrm{V}^{+-}$
$\mathrm{II}^{+-}$
$\mathrm{I}^{+}$


$\mathrm{II}^{+}$
$\mathrm{I}^{+}$
$\mathrm{I}^{+}$
$\mathrm{I}^{+}$
$\mathrm{I}^{+}$
$\mathrm{I}^{+}$

$\begin{array}{lll}\mathrm{III}^{+-1} & \mathrm{I}^{+} & \mathrm{I}^{+} \\ \mathrm{I}^{+} & \mathrm{I}^{+} & \mathrm{I}^{+} \\ \mathrm{I}^{+} & & \\ & \mathrm{I}^{+} & \mathrm{III}^{+-1} \\ & \mathrm{I}^{+} & \mathrm{I}^{+} \\ & & \mathrm{I}^{+}\end{array}$

$\mathrm{I}^{+}$

$\mathrm{I}^{+}$

$\mathrm{I}^{1}$

$\mathrm{I}^{+-1} \quad \mathrm{I}^{+}$

$\mathrm{I}^{+}$

$\mathrm{I}^{+}$ 
nations of $\mathrm{Ca}^{2+}$, total $\mathrm{Fe}$ and $\mathrm{PO}_{4}{ }^{3-}$ each substrate sample containing $1 \mathrm{~g}$ of dry matter was first digested in $20 \mathrm{ml} 1: 1$ $\mathrm{HCl}$ within 2 hours and then $100 \mathrm{ml}$ of demineralized water were added (acid extracts). After 24 hours all the extracted solutions were filtered with $3 \mathrm{~m}$-paper, rinsed with small amounts of demineralized water and the final quantities of the solutions were adjusted to $250 \mathrm{ml}$. Concentrations of $\mathrm{K}^{+}$and $\mathrm{Na}^{+}$in substrate were determined in $100 \mathrm{ml}$ water solutions extracted with $2 \mathrm{ml} \mathrm{1:1} \mathrm{HCl}$ from ignited samples. The analyses from water and acid extracts, the determinations of $\mathrm{Na}^{+} \mathrm{K}^{+}$and $\mathrm{pH}$ were conducted by the methods described above. Hydration was determined by drying substrate samples at $105^{\circ} \mathrm{C}$ to constant weight. Organic matter content was assessed by ignition of dry samples at $550^{\circ} \mathrm{C}$ for $1.5 \mathrm{~h}$.

Numerical data were evaluated statistically. The vegetation-habitat relationships were analysed by means of Canonical Correspondence Analysis (CCA) using CANOCO for Windows Version 4.0 (Ter Braak and Šmilauer 1998). Two sets of data were analysed separately: phytocoenoses-water properties and phytocoenoses-substrate properties. Moreover the habitat conditions of the three types of phytocoenoses investigated were compared with respect to each property using quartiles (Kendal and Buckland 1986). The significance of differences in water and substrate properties between the phytocoenoses investigated were determined by one-way analysis of variance and the Tukey test (Zar 1984). The $\mathrm{pH}$ values were recalculated so as to obtain specific acidity according to Wherry (1922).

\section{RESULTS}

Phytosociological characteristics of the phytocoenoses and their distribution within the lakes

On the basis of phytosociological data (Table 1) it was demonstrated that the three types of phytocoenoses analysed were distinct with respect to their floristic composition. The phytocoenoses dominated by $M$. alterniflorum from the Łęczna-Włodawa Lake District differed most considerably from the other phytocoenoses studied. Species from the Littorelletea uniflorae class, with the exception of $M$. alterniflorum, were absent. The following species from the Potametea class played an important role in the community structure: Myriophyllum spicatum (V constancy class), Potamogeton natans, Stratiotes aloides and Elodea canadensis (II constancy class). There was also a high contribution of such species as Phragmites australis (III constancy class) from the Phragmitetea class. In both types of the phytocoenoses investigated from the Pomeranian Lobelia lakes, species of the Littorelletea uniflorae class were most abundant. In addition to $M$. alterniflorum, a high proportion of Lobelia dortmanna and Isoëtes lacustris (IV constancy class) was noted in the phytocoenoses with L. uniflora. They were also characterised by a high proportion among companions of Eleocharis palustris from the Phragmitetea (III constancy class) and Polygonum amphibium (Potametea) - II constancy class. In the Pomeranian lakes M. alterniflorum dominated phytocoenoses had a lower proportion of Littorelletea uniflorae species. L. dortmanna, Luronium natans and L. uniflora were fairly constant (II constancy class), whereas I. lacustris was noted only in two patches

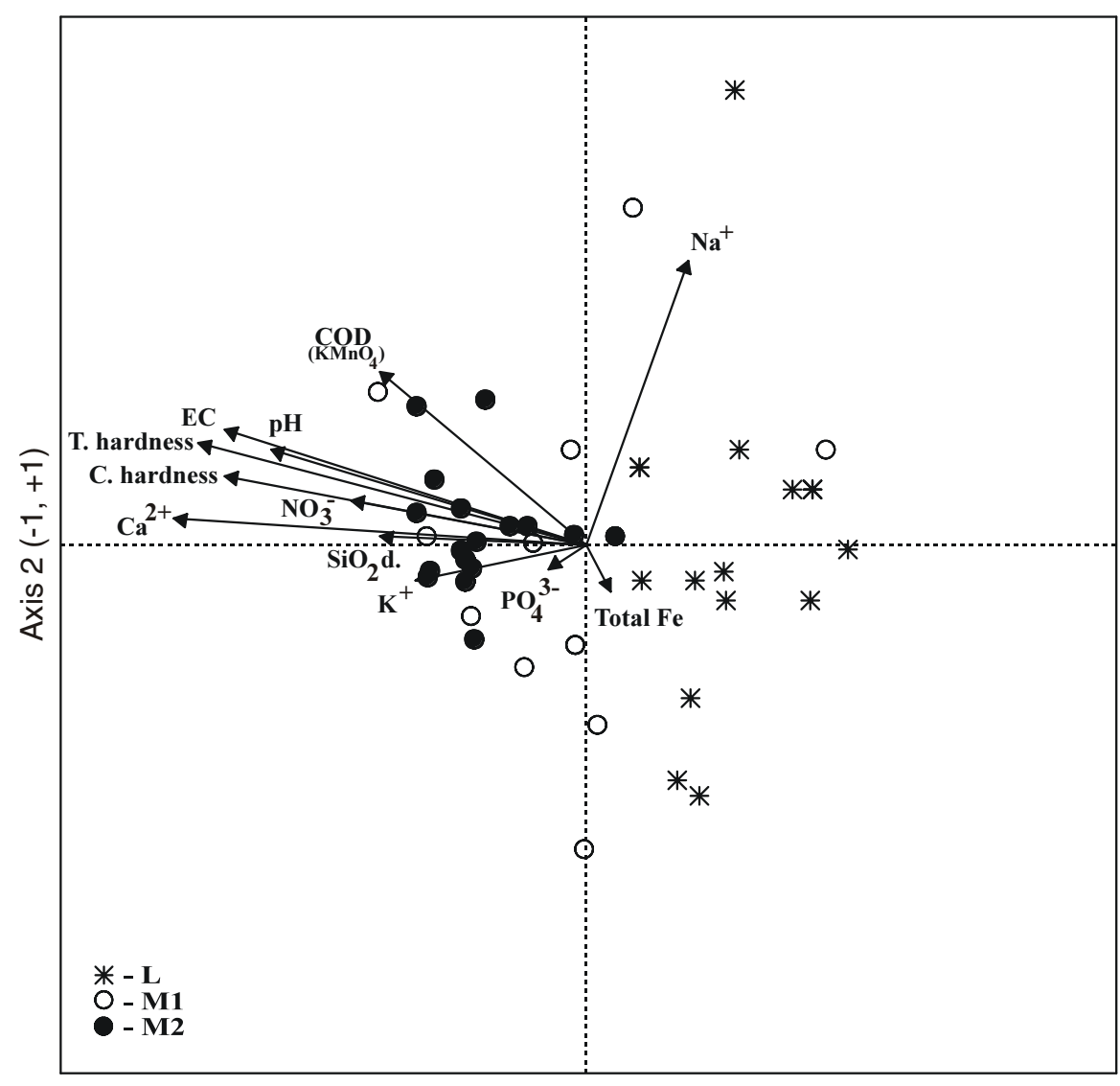

Axis $1(-1,+1)$
Fig. 1. An ordination diagram of CCA performed on 12 properties of water and 46 relevés. Eigenvalues: $\lambda 1=0.59$ (horizontal axis), $\lambda 2=0.09$ (vertical axis), $\lambda 3=0.05$, $\lambda 4=0.03, \Sigma \lambda=1.98 .1^{\text {st }}$ and $2^{\text {nd }}$ axes. $L-$ phytocoenoses of Littorella uniflora $(\mathrm{n}=16), \mathrm{M} 1$ - phytocoenoses of Myriophyllum alterniflorum from Lobelia lakes ( $\mathrm{n}=13), \mathrm{M} 2$ - phytocoenoses of Myriophyllum alterniflorum from the Łęczna-Włodawa Lake District $(\mathrm{n}=17)$. The overlapping points could not be displayed. 

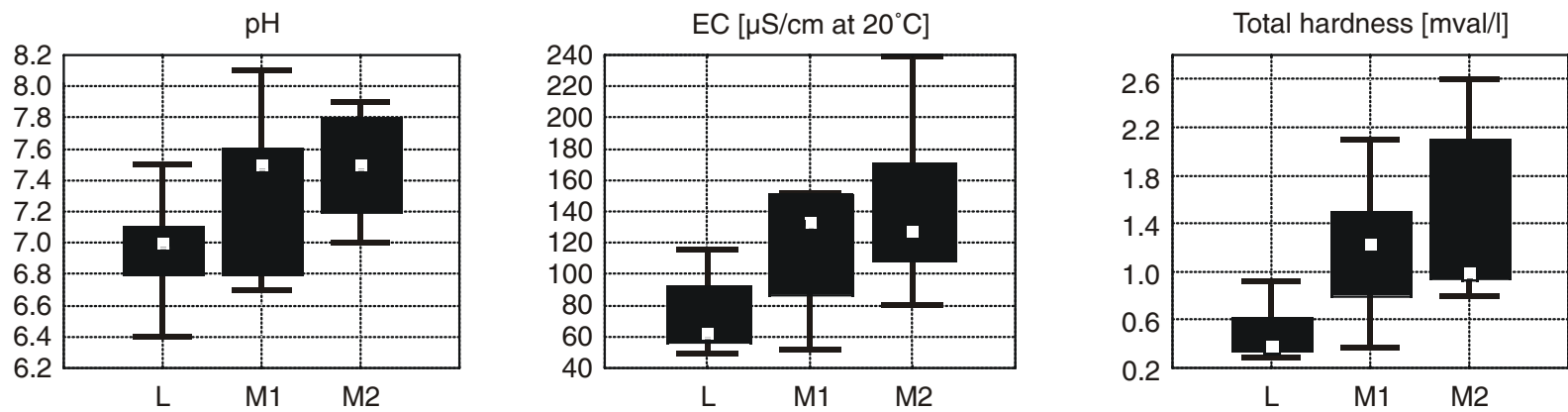

\section{Carbonate hardness [mval/l]}
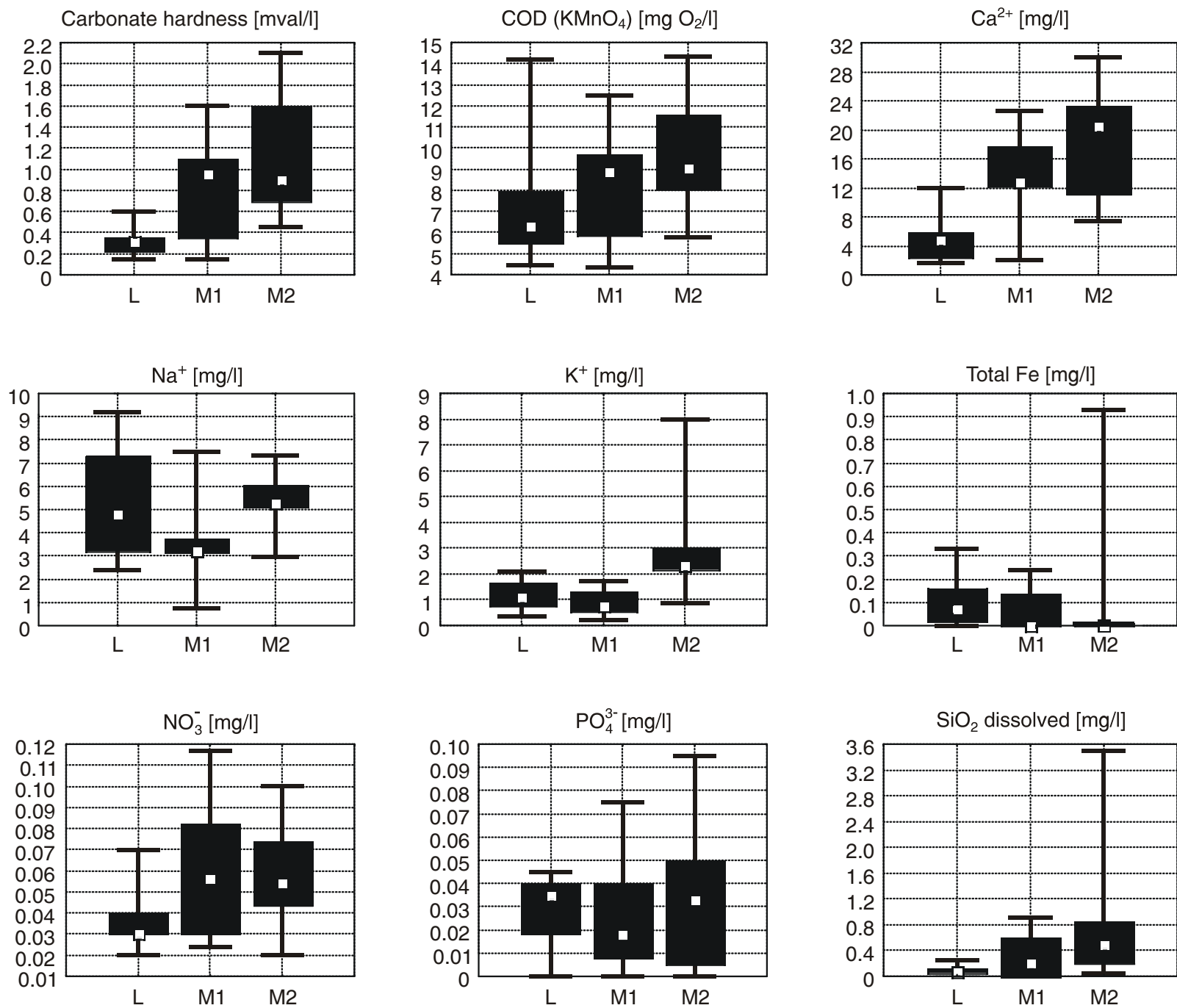

Fig. 2. Differentiation of the three types of phytocoenoses studied in relation to 12 properties of water. Black boxes show $25-75 \%$ interquartile ranges of values and white boxes show medians. L - phytocoenoses of Littorella uniflora ( $\mathrm{n}=16)$, M1 - phytocoenoses of Myriophyllum alterniflorum from Lobelia lakes ( $\mathrm{n}=13)$, M2 - phytocoenoses of Myriophyllum alterniflorum from the Łęczna-Włodawa Lake District $(\mathrm{n}=17)$.

(I constancy class). There was a relatively high incidence of the Potametea species (E. canadensis - III constancy class and M. spicatum - II constancy class).

Considerable differences in the spatial distribution of the three types of phytocoenoses investigated within the lake littoral were also found. In the Pomeranian lakes the phytocoenoses dominated by L. uniflora were restricted to the most shallow parts of the littoral zone. They occurred at a depth of $0-1.1 \mathrm{~m}$. The patches dominated by M. alterniflorum developed at a depth ranging from 0.2 to $2.1 \mathrm{~m}$. The $M$. alterniflorum phytocoenoses from the Łęczna-Włodawa
Lake District displayed the widest range of depth (0.3-2.5 $\mathrm{m})$. Both types of the phytocoenoses from the Pomeranian lakes were associated with mineral-sandy bottoms. Most of the phytocoenoses from the Łęczna-Włodawa Lake District showed also preference for mineral substrates. However, some of them were found to occur abundantly on organic substrates as well.

\section{Physical and chemical properties of water}

It appears that such properties as calcium and factors associated with carbonate complex (carbonate and total hard- 
TABLE 2. The significance of differences in water properties between the three types of phytocoenoses compared. $+=$ significant at $\mathrm{P}<0.05$, ns $=$ not significant. Symbols of phytocoenoses - see Table 1 .

\begin{tabular}{|c|c|c|c|}
\hline Properties & L-M1 & L-M2 & M1-M2 \\
\hline $\mathrm{pH}$ & + & + & ns \\
\hline Electrolytic conductivity (EC) & + & + & + \\
\hline Total hardness & + & + & ns \\
\hline Carbonate hardness & + & + & ns \\
\hline COD-KMnO & ns & + & ns \\
\hline $\mathrm{Ca}^{2+}$ & + & + & ns \\
\hline $\mathrm{Na}^{+}$ & + & ns & + \\
\hline $\mathrm{K}^{+}$ & ns & + & + \\
\hline $\mathrm{NO}_{3}^{-}$ & ns & ns & ns \\
\hline $\mathrm{PO}_{4}^{3-}$ & ns & ns & ns \\
\hline $\mathrm{SiO}_{2}$ dissolved & $\mathrm{ns}$ & + & ns \\
\hline
\end{tabular}

ness, electrolytic conductivity and $\mathrm{pH}$ ) differentiate the phytocoenoses investigated much better than the other components (Figs 1 and 2). These variables are strongly correlated with the first ordination axis (Fig. 1) and clearly separate the water habitats of the phytocoenoses dominated by L. uniflora in the Pomeranian lakes from those dominated by $M$. alterniflorum in the Łęczna-Włodawa Lake District. The former are characterized by significantly lower values of the above mentioned properties (see Table 2). They inhabit very soft waters, considerably poor in $\mathrm{Ca}^{2+}$ and with the lowest values of $\mathrm{pH}$ and electrolytic conductivity. The phytocoenoses with $M$. alterniflorum from the Łęczna-Włodawa Lake District show preference for harder alkaline waters, richer in $\mathrm{Ca}^{2+}$ (see Fig. 2). The habitats of the phytocoenoses dominated by $M$. alterniflorum from the Pomeranian Lobelia lakes occupy an intermediate position with respect to the above properties of water (Fig. 2). Other variables such as $\mathrm{K}^{+}$, dissolved $\mathrm{SiO}_{2}, \mathrm{NO}_{3}{ }^{-}$and $\mathrm{COD}-\mathrm{KMnO}_{4}$ (Fig. 1) differentiate the water habitats in a similar way. Phosphates and total iron play the least significant role in the CCA model (the shortest arrows). With regard to these two properties and $\mathrm{NO}_{3}{ }^{-}$, there are no significant differences between the water habitats studied (Table 2). In the case of $\mathrm{Na}^{+}$, which is correlated with the second ordination axis (Fig. 1), there are no significant differences between the water habitats of the phytocoenoses with L. uniflora and those of $M$. alterniflorum from the Łęczna-Włodawa Lake District (Table 2). From Fig. 2 and Table 2 it is clear that considerable differences between the $M$. alterniflorum phytocoenoses from the Pomeranian Lobelia lakes and those dominated by $M$. alterniflorum from the Łęczna-Włodawa Lake District are detected regarding their $\mathrm{Na}^{+}$concentration.

\section{Physical and chemical properties of substrate}

The analysis of the data given in Figs 3 and 4 showed that the substrates of the studied phytocoenoses differed most distinctly with respect to $\mathrm{pH}$, which was correlated with the first and second ordination axis to the same degree. The L. uniflora dominated phytocoenoses (Pomerania) inhabit the most acidic substrates (mainly with $\mathrm{pH}$ 5.1-6.1), whereas the patches with $M$. alterniflorum from the Łęczna-Włodawa Lake District occur on slightly acidic substrates ( $\mathrm{pH}$ 6.2-6.8). The M. alterniflorum dominated phytocoenoses from Pomerania are confined to substrates with $\mathrm{pH}$ ranging from 5.8 to 6.3 (see Fig. 4). The other 8 properties (except for $\mathrm{PO}_{4}{ }^{3-}$ ) are correlated with $\mathrm{pH}$ (Fig. 3 ) and they differentiate the habitats in a similar way (Figs

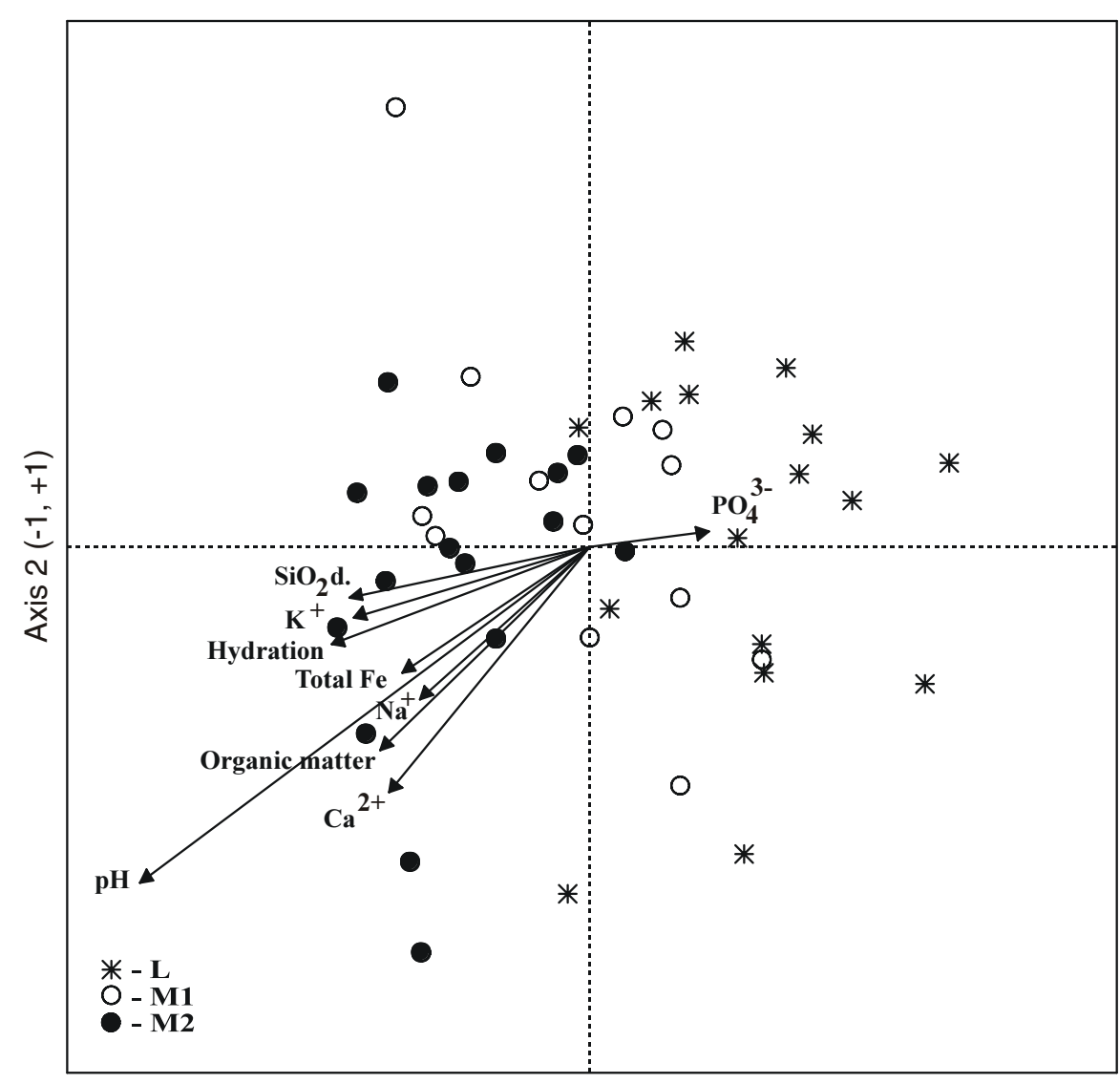

Axis $1(-1,+1)$
Fig. 3. An ordination diagram of CCA performed on 9 properties of substrate and 46 relevés. Eigenvalues: $\lambda 1=0.46$ (horizontal axis), $\lambda 2=0.06$ (vertical axis), $\lambda 3=0.05$, $\lambda 4=0.04, \Sigma \lambda=1.98 .1^{\text {st }}$ and $2^{\text {nd }}$ axes. The overlapping points could not be displayed. For symbols and number of phytocoenoses see Figure 1. 

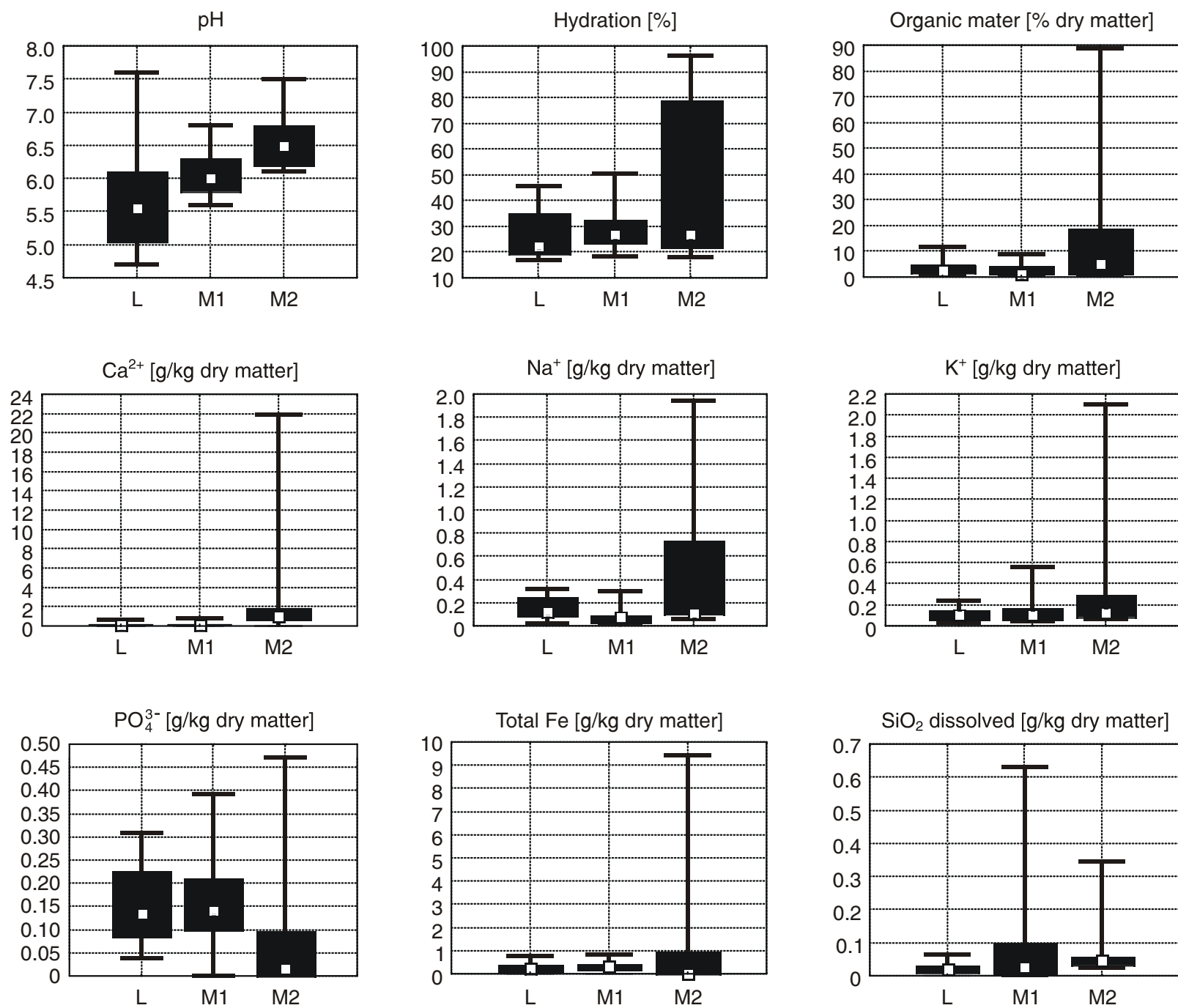

Fig. 4. Differentiation of the three types of phytocoenoses studied in relation to 9 properties of substrate. Black boxes show $25-75 \%$ interquartile ranges of values and white boxes show the medians. For symbols and number of phytocoenoses see Figure 2.

TABLE 3. The significance of differences in substrate properties between the three types of phytocoenoses compared. $+=$ significant at $\mathrm{P}<0.05$, $\mathrm{ns}=$ not significant.

Symbols of phytocoenoses - see Table 1 .

\begin{tabular}{lccc}
\hline Properties & L-M1 & L-M2 & M1-M2 \\
\hline $\mathrm{pH}$ & + & + & $\mathrm{ns}$ \\
Hydration & $\mathrm{ns}$ & + & $\mathrm{ns}$ \\
Organic matter & $\mathrm{ns}$ & + & $\mathrm{ns}$ \\
$\mathrm{Ca}^{2+}$ & $\mathrm{ns}$ & $\mathrm{ns}$ & $\mathrm{ns}$ \\
$\mathrm{Na}^{+}$ & + & $\mathrm{ns}$ & + \\
$\mathrm{K}^{+}$ & $\mathrm{ns}$ & + & $\mathrm{ns}$ \\
$\mathrm{PO}_{4}^{3-}$ & $\mathrm{ns}$ & $\mathrm{ns}$ & $\mathrm{ns}$ \\
$\mathrm{Total} \mathrm{Fe}_{\mathrm{SiO}}$ dissolved & $\mathrm{ns}$ & $\mathrm{ns}$ & $\mathrm{ns}$ \\
\hline
\end{tabular}

3 and 4). This mainly applies to such properties as hydration, organic matter content, $\mathrm{K}^{+}, \mathrm{Ca}^{2+}$ and dissolved $\mathrm{SiO}_{2}$. As in the case of $\mathrm{pH}$, the above properties differentiate the substrates of the L. uniflora dominated phytocoenoses in the Pomeranian Lobelia lakes (lower values of the abovementioned properties) from those dominated by M. alterniflorum in the Łęczna-Włodawa Lake District (higher values of properties). Significant differences were, however, found only in the case of hydration, organic matter content and $\mathrm{K}^{+}$(Table 3). The substrates of the phytocoenoses with $M$. alterniflorum from Pomerania have intermediate values of the above properties analysed. In addition, they contain the lowest amount of $\mathrm{Na}^{+}$(Fig. 4, Table 3). A reverse trend was determined in the case of $\mathrm{PO}_{4}{ }^{3-}$ (Figs 3 and 4). It was demonstrated that the substrates inhabited by the phytocoenoses from the Łęczna-Włodawa Lake District were poorer in $\mathrm{PO}_{4}{ }^{3-}$ than those from the Pomeranian Lake District.

\section{DISCUSSION}

\section{Myriophylletum alterniflori or Myriophyllo-Littorelletum?}

The present results confirm that like other plant communities of the Littorelletea uniflorae class in Poland (Szańkowski and Kłosowski 2001, 2002), the three types of phytocoenoses analysed in this study are associated with waters poor in $\mathrm{Ca}^{2+}$ and mostly with acidic substrates containing a low amount of calcium. The current findings, however, indicate that the investigated phytocoenoses are distinct with respect to habitat conditions, which is ascribed to the regional differences between the waters and dominance of different species. It was demonstrated that the phytocoeno- 
ses of L. uniflora differed considerably from the two types of phytocoenoses of $M$. alterniflorum. In addition the habitats of $M$. alterniflorum phytocoenoses with L. uniflora in the Pomeranian Lobelia lakes were more similar to those of $M$. alterniflorum in the Łęczna-Włodawa Lake District than to the phytocoenoses of L. uniflora with M. alterniflorum in the Pomeranian Lobelia lakes. Therefore floristic dominance plays an important role in distinguishing these communities. This suggested that the phytocoenoses of L. uniflora and those of $M$. alterniflorum should be treated separately. The separation of the L. uniflora phytocoenoses in Pomerania from those of $M$. alterniflorum in the Łęczna-Włodawa Lake District is fully justified (the lack of similarities in their floristic composition is confirmed by their habitat distinctness). In the case of $M$. alterniflorum phytocoenoses from the Pomeranian Lobelia lakes the problem is much more complicated. Earlier phytosociological data (Dąmbska 1965; Kreńska 1971; Michna 1976; Szmeja and Clément 1990) showed that L. uniflora and M. alterniflorum occurred jointly in the same patches and thus were recognized as the character species of one association (Myriophylletum alterniflori or Myriophyllo-Littorelletum) which was associated with Lobelia lakes. The above findings are in agreement with the present results, which point to a fairly high contribution of $M$. alterniflorum to the L. uniflora dominated phytocoenoses and vice versa. In addition both types of phytocoenoses were similar with respect to their floristic composition (a considerable contribution of Littorelletea uniflorae species). As significant differences between the habitats of the above two types of phytocoenoses in the Lobelia lakes have been found therefore the following question needs to be answered: Do the phytocoenoses differ to such an extent that they could be considered as distinct communities or do the differences simply manifest the internal ecological variability within the association? If the principles of phytosociology are considered, the latter assumption seems justified. Such an ecological differentiation of phytocoenoses was indicated in the case of other water and reedswamp plant communities, e.g. Elodeetum canadensis (Kłosowski and Tomaszewicz 1997) and Phragmitetum australis (Pełechaty 1997). The above studies should also include the phytocoenoses of $M$. alterniflorum from the Pomeranian non-Lobelia lakes and those in which $M$. alterniflorum and L. uniflora are the codominant species. At present only the phytocoenoses from the Łęczna-Włodawa Lake District can be considered as a distinct association (Myriophylletum alterniflori). Perhaps the patches with $M$. alterniflorum which occur in the non-Lobelia lakes within the Pomerania in the region of Laska (Rejewski 1981), should be included in the above association as well. This is supported by data obtained by the present authors from Lake Zmarłe near Laska. In this lake the patches with $M$. alterniflorum developed in waters with total hardness of $1.7 \mathrm{mval} / \mathrm{l}$ and calcium concentration $33.6 \mathrm{mg} / \mathrm{l}$. Thus their habitats are similar to those reported from the Łęczna-Włodawa Lake District. Perhaps these phytocoenoses should not be included in the Littorelletea uniflorae class (see Den Hartog 1981, Rejewski 1981). There is no doubt that the phytocoenoses dominated by L. uniflora and/or M. alterniflorum from the Lobelia lakes, in which the contribution of Littorelletea uniflorae species is appreciable, belong to this class. Therefore if the association Myriophyllo-Littorelletum is recognized, only these phytocoenoses should be included in this association.
The above findings are supported by the present results concerning the properties which are of major importance in differentiating the waters of the investigated phytocoenoses (calcium, total hardness, electrolytic conductivity - see Fig. 2), and by earlier data obtained for some communities of the Littorelletea uniflorae class, namely Lobelietum dortmannae, Isoëtetum lacustris and Luronietum natantis (Szańkowski and Kłosowski 2001). The maximum values of these properties for the above communities were as follows: Lobelietum dortmannae - $17.6 \mathrm{mg} / \mathrm{l}\left(\mathrm{Ca}^{2+}\right) ; 1.50 \mathrm{mval} / \mathrm{l}$ (total hardness); $154 \mu \mathrm{S} / \mathrm{cm}$ (electrolytic conductivity), Isoëtetum lacustris - $12.0 \mathrm{mg} / \mathrm{l} ; 0.80 \mathrm{mval} / \mathrm{l} ; 72 \mu \mathrm{S} / \mathrm{cm}$, Luronietum natantis - $3.1 \mathrm{mg} / \mathrm{l} ; 0.62 \mathrm{mval} / \mathrm{l} ; 94 \mu \mathrm{S} / \mathrm{cm}$. From these data and Figure 2, it is clear that the maximum values of the above properties are much higher in the case of $M$. alterniflorum phytocoenoses from the Łęczna-Włodawa Lake District $\left(\mathrm{Ca}^{2+}-30 \mathrm{mg} / \mathrm{l}\right.$; total hardness - $2.60 \mathrm{mval} / \mathrm{l}$; electrolytic conductivity $239 \mu \mathrm{S} / \mathrm{cm}$ ). Thus the ecological amplitude of these phytocoenoses is wider than that of the typical communities of Littorelletea uniflorae. The waters of the phytocoenoses of L. uniflora appeared to be similar to those of Isoëtetum lacustris and Luronietum natantis with low values of $\mathrm{Ca}^{2+}$ and total hardness, whereas those of M. alterniflorum from the Lobelia lakes were similar to those of Lobelietum dortmannae.

The comparison of the habitats of Myriophyllum alterniflorum and Littorella uniflora phytocoenoses in Europe and Poland

The phytocoenoses dominated by either M. alterniflorum or L. uniflora have been included in the Isoëto-Lobelietum (Koch 1926) Tx. 1937 association by European phytosociologists (e.g. Szmeja and Clément 1990), or assigned different names depending on the co-occurrence of other species. Such communities as Myriophyllo-Littorelletum Jeschke 1959, Myriophylletum alterniflori Lemée 1937 em. Siss. 1943, Myriophylletum alterniflori Westhoff mscr. 1944, Callitricho hamulatae-Myriophylletum alterniflori (Steusloff 1939) Weber-Oldecop 1967 and Myriophyllo alterniflori-Potametum praelongi (Pietsch 1984) ass. now. (see Vöge 1993) have been described. The following communities which have no fixed syntaxonomic rank have also been recognized, e.g. Littorella uniflora und Baldellia ranunculoides-Gesellschaft (Pott 1982), Littorella uniflora-Gesellschaft (Dierssen 1975, 1996), Littorella-Potamogeton filiformis-Soz. Schoof van Pelt and Westfoff 1969 (Dierssen 1975), Myriophyllum alterniflorum - Gesellschaft (Dierssen 1996), groupment à Littorella uniflora et M. alterniflorum (Szmeja and Clément 1990), Potamogeton perfoliatus-Myriophyllum alterniflorum community (Rodwell 1995).

The names of the aforementioned communities which point to the presence of species belonging to other classes than Littorelletea uniflorae reflect the wide coenological amplitude of these communities. This is confirmed by habitat data obtained for M. alterniflorum, L. uniflora and their phytocoenoses which are characterized by various floristic composition (Pietsch 1982, 1984; Vöge 1993). According to Pietsch (1982) both M. alterniflorum and L. uniflora develop in waters with a wide range of hardness: from soft (minimum values of total hardness: L. uniflora - 0.036 mval/l; M. alterniflorum - $1.46 \mathrm{mval} / \mathrm{l}$ ) to hard waters (maximum values: L. uniflora - $6.42 \mathrm{mval} / \mathrm{l} ; M$. alteriflorum $4.28 \mathrm{mval} / \mathrm{l})$. Hence L. uniflora can be found in much har- 
der waters than $M$. alterniflorum. However this does not apply to the species reported from Poland. In the case of $L$. uniflora Pietsch (1982) also indicated wider ranges of $\mathrm{pH}$ : 4.6-9.0 (M. alterniflorum: 4.6-7.5) and higher maximum values of $\mathrm{Ca}^{2+}$ (L. uniflora $-80 \mathrm{mg} / \mathrm{l} ;$ M. alterniflorum -60 $\mathrm{mg} / \mathrm{l})$. In the Mecklemburg Lake District in Germany the maximum values of total hardness for L. uniflora $(2.42$ mval/l) are lower (Pietsch 1982) than those for M. alterniflorum (3.96 mval/l). Vöge (1993) investigated the habitats of $M$. alterniflorum in 70 lakes in central and northern Europe with regard to $\mathrm{pH}$, total hardness, alkalinity, electrolytic conductivity. The author indicated the presence of M. alterniflorum and the phytocoenoses formed by it (with L. uniflora as well) in oligotrophic waters with total hardness of $0.14-0.54 \mathrm{mval} / \mathrm{l}$, as well as in oligo-mesotrophic lakes (range of water hardness: 1.71-3.21 mval/l). The proportion of species characteristic of Littorelletea uniflorae declined considerably while passing from oligotrophic to oligo-mesotrophic lakes. L. uniflora was found in some meso-eutrophic lakes.

It appears that in Poland the phytocoenoses dominated by either L. uniflora or by M. alterniflorum in which the contribution of Littorelletea uniflorae species is appreciable are clearly associated with soft waters and their habitats are representative of the Littorelletea uniflorae class when the data from other regions of Europe are considered. The massive development of the phytocoenoses with both $L$. uniflora and M. alterniflorum in the Lobelia lakes is not always indicative of the increase in water hardness and euthrophication of waters typical of the communities of the Littorelletea uniflorae class. The $M$. alterniflorum dominated phytocoenoses in which other Littorelletea species are absent, could be good indicators of the above processes taking place in such water ecosystems.

\section{LITERATURE CITED}

BOIŃSKI M., BOIŃSKA U. 1988. Roślinność jezior lobeliowych okolic Strugi Ośmiu Jezior (Bory Tucholskie). AUNC, Ser. Biol. 29, 63: 53-77. (in Polish with German summary)

DĄMBSKA I. 1965. Roślinność litoralu jezior lobeliowych Pojezierza Kartuskiego. PTPN, Prace Kom. Biol. 30: 1-53. (in Polish with English summary)

DEN HARTOG C. 1981. Synecological classification of aquatic plant communities. Coll. Phytosoc. (Végétations aquatiques) 10: $171-182$.

DIERßEN K. 1975. Prodromus der europäischen Pflanzengesellschaften. Lfg. 2. Littorelletea uniflorae. Cramer, Vaduz, pp. 149.

DIERßEN K. 1996. Vegetation Nordeuropas. Ulmer, Stuttgart, pp. 838.

FIJAŁKOWSKI D. 1959. Szata roślinna jezior Łęczyńsko-Włodawskich i przylegających do nich torfowisk. Ann. UMCS, Sec. B, 14, 3: 131-206. (in Polish with English summary)

KENDALL M.G., BUCKLAND W.R. 1986. Słownik terminów statystycznych. Państwowe Wyd. Ekonomiczne, Warszawa, pp. 312. (in Polish)

KŁOSOWSKI S. 1994. Ekologia głównych zbiorowisk roślin wodnych z klasy Littorelletea uniflorae Br.-B1. et Tx. 1943 w Polsce. In: Jeziora Lobeliowe. Charakterystyka, funkcjonowanie i ochrona. Cz. I. Kraska M. (ed.). Idee ekologiczne, Tom 6, Ser. Szkice 4: 93-104. (in Polish with English summary)

KŁOSOWSKI S., TOMASZEWICZ H. 1989. Habitat conditions of the phytocoenoses of Myriophylletum alterniflori Lemée em.
Siss. 1943, Myriophylletum verticillati Soó 1927 and Myriophylletum spicati Soó 1927 in Poland. Aquat. Bot. 35: 337 $-356$.

KŁOSOWSKI S., TOMASZEWICZ H. 1997. Zur Soziologie und. Ökologie des Hydrilletum verticillatae Tomaszewicz 1979 und des Elodeetum canadensis (Pign. 1953) Pass. 1964 in Nordost-Polen. Tuexenia 17: 125-136.

KREŃSKA B. 1971. Roślinność naczyniowa jeziora Otalżyno i jeziora Kamień na Pojezierzu Kaszubskim. Bad. Fizjogr. Pol. Zach., Ser. B. Botanika 24: 159-180. (in Polish with English summary)

MATUSZKIEWICZ W. 1981. Przewodnik do oznaczania zbiorowisk roślinnych Polski, PWN, Warszawa, pp. 278. (in Polish)

MATUSZKIEWICZ W. 2001. Przewodnik do oznaczania zbiorowisk roślinnych Polski.Wyd. Nauk. PWN, Warszawa, pp. 537. (in Polish)

MICHNA I. 1976. Roślinne zbiorowiska jeziorne Pojezierzy Drawskiego i Bytowskiego. PTPN, Prace Kom. Biol. Tom 43: 1-74. (in Polish with English summary)

PEŁECHATY M. 1997. Wewnętrzne zróżnicowanie ekologiczne zespołu Phragmitetum (Gams 1927) Schmale 1939, a jego wartość bioindykacyjna. Mat. XVII Zjazdu Hydrobiol. Pol., Poznań, 8-11 September 1997: 227-227. (in Polish)

PIETSCH W. 1982. Makrophytische Indikatoren für okochemische Beschaffenheit der Gewässer. In: Ausgewahlte Methoden der Wasseruntersuchung. Breitig. G., Tumpling W (eds). Bd. 2. Gustav Fischer, Jena, pp. 67-88.

PIETSCH W. 1984. Zur Soziologie und und Ökologie von Myriophyllum alterniflorum DC in Mitteleuropa. Mitt. Arbeitsgem. Geobot. Schleswig-Holst. u Hamburg 33: 224-245.

PODBIELKOWSKI Z., TOMASZEWICZ H. 1979. Zarys Hydrobotaniki. PWN, Warszawa, pp. 531. (in Polish)

POTT R. 1982. Littorelletea-Gesellschaften in der Westfalischen Bucht. Tuexenia 2: 31-45.

REJEWSKI M. 1981. Roślinność jezior rejonu Laski w Borach Tucholskich. Rozprawy UMK, Toruń, pp. 178. (in Polish with English summary)

RODWELL J.S. (ed.). 1995. British plant communities. Vol. 4. Aquatic communities, swamps and tall-herb fens. Cambridge University Press, pp. 283.

SZAŃKOWSKI M. 1998. Ekologiczny status roślinności jezior lobeliowych w Polsce. Zakład Botaniki Środowiskowej, Wydz. Biologii UW, mscr., pp. 145. (in Polish with English summary)

SZAŃKOWSKI M., KŁOSOWSKI S. 1996. Habitat variability of the phytocoenoses of Isoëto-Lobelietum in Poland. Fragm. Flor. Geobot. 41: 255-267.

SZAŃKOWSKI M., KŁOSOWSKI S. 2001. Habitat conditions of the phytocoenoses dominated by Luronium natans (L.) Rafin in Poland. Hydrobiologia 455: 213-222.

SZAŃKOWSKI M., KŁOSOWSKI S. 2002. The plant communities of Littorelletea uniflorae as indicators of the variability of littoral habitats in Polish Lobelia lakes. In: Proceedings of the $11^{\text {th }}$ EWRS International Symposium on Aquatic Weeds, Moliets et Maâ (France), September 2-6 2002, pp. 255-258.

SZMEJA J., CLÉMENT B. 1990. Comparaison de la structure et du déterminisme des Littorelletea uniflorae en Poméranie (Pologne) et en Bretagne (France). Phytocoenologia 19: 123-148.

TER BRAAK C.J.F., ŠMILAUER P. 1998. CANOCO Reference Manual and User's Guide to Canoco for Windows. Software for Cannonical Community Ordination (version 4). Centre for Biometry Wageningen (Wageningen, NL) and Microcomputer Power (Ithaca NY, U.S.A): pp. 352.

VÖGE M. 1993. Tauchexkursionen zu Standorten von Myriophyllum alterniflorum DC. Tuexenia 13: 91-108.

WHERRY E.T. 1922. Note on specific acidity. Ecology 3: 346$-347$.

ZAR J.A. 1984. Biostatistical Analysis. Prentice-Hall, Inc., Englewood Cliffs, New Jersey, pp. 718. 